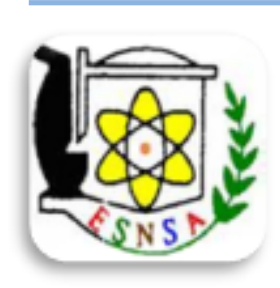

Arab Journal of Nuclear Sciences and Applications

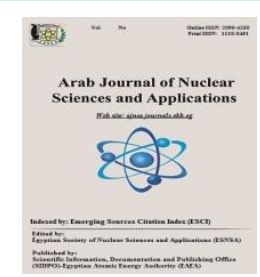

(ESNSA)

\title{
Improved Productivity of Superior Seedless Grapevines Using Irradiated Compost and Bio-Fertilization in the Desert Land
}

\author{
M.F.Ahmed ${ }^{1}$ and M.N. Mohamed ${ }^{2}$ \\ ${ }^{1}$ Natural Products Department, National Centerfor Radiation Research and Technology, Atomic Energy \\ Authority, Cairo, Egypt \\ ${ }^{2}$ Viticulture Department, Horticulture Research Institute, Agricultural Research Center, Giza, Egypt
}

Received $6^{\text {th }}$ Dec. 2017 The application of some biofertilizers and irradiated compost for replacement of NPK chemical Accepted $8^{\text {th }}$ Jan. 2018 fertilizers was studied on fiveyear-old superior seedless grapevine to determine the best dosage that would improve growth, yield and berry characteristicsand reduce the rates of mineral fertilizations of NPK without any negative effect. The experiment was conducted in a vineyard located at CairoAlexandria Desert Road in 2015 and 2016 seasons. The experiment consisted of six treatments, namely, $100 \%$ NPK (control), $100 \%$ NPK + microbein, $50 \%$ NPK + $50 \%$ irradiated compost (IC), 50\% NPK + $50 \%$ irradiated compost + microbein, $100 \%$ irradiated compost and $100 \%$ irradiated compost + microbein. All treatments were very effective in stimulating growth characters as well as physical and chemical characteristics of the berries in relation to the control treatment. Petiole NPK \%, leaf chlorophyll content and cane carbohydrate content were increased more than the control. In addition, the cluster weight was significantly increased and as a result, yield per vine was increased. The highest superior effect was recorded in response to $100 \%$ IC + microbein application. This improvement could be attributed to the positive influence upon the biosynthesis of the primary metabolites (soluble carbohydrates, chlorophyll and carotenoid pigments) and secondary metabolites (proteins, polyphenols, auxins). In addition, both compost especially when irradiated and biofertilizers increase the availability and uptake of $\mathbf{N}, \mathbf{P}$ and $\mathrm{K}$, which was reflected on the growth parameters. Finally, irradiated compost alone or combined with microbein could be used as a valid alternative method to the expensive hazardous mineral fertilizers.

Keywords: Biofertilization/ Irradiated Compost/ Superior Seedless/ NPK

\section{Introduction}

Cluster quality plays an important role in marketing table grapes. The use of some mineral fertilizers to increase the berry size should be very carefully considered, as it can cause problems. However, some producers use them because an increase in berry diameter may contribute to an increase in yield [1]. The most important crop nutrients in agricultural systems are nitrogen $(\mathrm{N})$, phosphorus (P), and potassium (K) [2]. Nitrogen fertilization affects the newly introduced cultivars of grapevines; especially sources and methods of its application [3]. Potassium, an essential element, intensifies the synthesis of carbohydrates and proteins, catalyzes the activity of some enzymes, promotes the synthesis and accumulation of thiamin and riboflavin and is essential for the activity of guard cells.Phosphorus plays important roles in biosynthesis, respiration, energy storage, cell division, translocation of carbohydrates and fruit development. Its deficiency negatively affects fruits quality [4]. Increased $\mathrm{N}$ supply has the advantages of increasing the annual biomass production and yield. However too much $\mathrm{N}$ adversely affects the anthocyanin content and fastens the fermentation process [5].

Corresponding author: ms omarmohamed@yahoo.com 
Over the past decades, chemical fertilizers were considered as the most important contributor to the increase of agricultural productivity [6]. However their continuous use leads to the deterioration of soil characteristics and fertility affecting crops nutritional value and edibility [7]. Moreover, the request of organic crops consumption has been increased around the world in the last few decades [8]. Therefore, there is a need to investigate the use of alternative cultivation practices; among them were organic and biological fertilizers.

Organic fertilization improves the soil structure, helps retention of moisture and reduces the soil $\mathrm{pH}$. Also, it promotes plant growth, increases nutrient content, crop productivity, facilitates the implementation of different types of soil, and adds economic benefits for farmers [9]. In addition, it could reduce the application of industrial fertilizers in the long term [10]. Soil organic fertilization have a positive effect on the biosynthesis of the primary metabolites (soluble carbohydrates, chlorophyll and carotenoid pigments) and secondary metabolites (proteins, polyphenols, auxins) of grapevine, during the vegetation season [11]. Gamma irradiation of sludge increased the amount of dissolved organic matter, availability and uptake of essential elements, mineral content of fruits and fresh and dry weight of plants [12]. Gamma- irradiated compost, as compared to mineral fertilizer, produced the highest maize yield (4.4 ton/ha) among all other treatments, while mineral fertilizer produced 3.9 ton/ha. Some researchers concluded that the compost irradiated by gamma-irradiation produces similar or higher maize yields than mineral fertilizer [13].

Biological fertilization relies on the application of natural fertilizers, decaying remains of organic matter, animal manure, and microorganisms such as fungi and bacteria [14]. The application of biofertilizers has many advantages. This includes reducing plant requirements of nitrogen by $25 \%$ and environmental pollution while improving the availability and uptake of various nutrients for the plant absorption and productivity of the trees [15]. The aim of the present study was to evaluate the effect of NPK and irradiated compost alone or in combination with some biofertilizers on morphological and some chemical characteristics of superior grapes, as well as the concomitant effects on the quality of the clusters and yield to reduce the rates of mineral fertilizations (NPK) without any negative effect on crop yieldand quality.

\section{Materials and Methods}

The present work was conducted during three successive seasons 2014, (as a preliminary trial season) and 2015 and 2016 in a vineyard located at Cairo-Alexandria Desert Road. Five years-old superior seedless grapevines grown in a loamy sand soil and trellised by Spanish parron system, with line spacing $3.0 \times 3.5 \mathrm{~m}$ were used in this investigation. The vines were pruned during the last week of Decemberleaving6 Cans x 10 buds each with a total vine load of 60 buds. Vines were irrigated through drip irrigation system. Fifty four uniform vines were chosen for this study (6 treatments $\mathrm{x} 3$ replicates $\mathrm{x} 3$ vines /replicate). The vines were uniform in vigor and received common horticultural practices. Clusters per vine were adjusted to 40 cluster.

The mineral fertilization NPK (M) was added as N ( $125 \mathrm{~g} /$ vine per season), $\mathrm{P}$ (62.5 g/vine per season) and $\mathrm{K}(187.5 \mathrm{~g} /$ vine per season) vineyard treatment (control). The compost was exposed to gamma irradiation using Co60 gamma source at a dose level of $15 \mathrm{kGy}$ (dose rate 3.13 and $2.73 \mathrm{KGy} / \mathrm{hr}$ for both season, respectively) at the National Center for Radiation Research and Technology (NCRRT). The biofertilizers were added in the form of microbein (Azotobacterchrococcum) at dose of $22 \mathrm{ml} / \mathrm{vine}$ (ministry of agriculture).

Irradiated compost (IC) and microbein (Bio) were added once to the soil before the beginning of bud burst at the second and third week of January, respectively at $30 \mathrm{~cm}$ depth then covered with the soil and irrigated with water. A randomized complete block design was used in this experiment. Six treatments were applied as follows:

$$
\begin{array}{ll}
\text { 1- } & 100 \% \mathrm{M}(\mathrm{NPK}) \\
\text { 2- } & 100 \% \mathrm{M}+\mathrm{Bio} \\
\text { 3- } & 50 \% \mathrm{M}+50 \% \mathrm{IC}(2 \mathrm{~kg} / \mathrm{vine}) \\
\text { 4- } & 50 \% \mathrm{M}+50 \% \mathrm{IC}+\mathrm{Bio} \\
5- & 100 \% \mathrm{IC}(4 \mathrm{~kg} / \mathrm{vine}) \\
\text { 6- } & 100 \% \mathrm{IC}+\text { Bio }
\end{array}
$$

The physical and chemical properties of the soil and compost were determined according to the method of soil analysis that outlined by Richards [16] and AOAC [17], respectively and presented in Tables (1\& 2). 
The following data were measured as follows: Morphological measurements of leaves and shoots

a- Average leaf area (cm2): Samples of leaves were randomly collected from each treatment for leaf area determination at harvest time (using leaf area meter, Model CI 203, U.S.A.).

b- Pruning weight/vine $(\mathrm{Kg})$ : It was measured at dormancy period (winter pruning) according to Selim et al. [18].

\section{Chemical characteristics of leaves and shoots}

a- Petiole mineral contents of NPK (\%) were determined in the oven- dried petiole samples of the leaf against the cluster that was collected at flowering stage. Nitrogen (\%) was determined by the modified micro-kejldahl method as described by Wilde et al. [19], Phosphorus (\%) and Potassium (\%) were determined using the Olsen and flame photometrically method, respectively as reported by Chapman and Pratt [20].

b- Leaf total chlorophyll content was measured in the mature 6th and 7th apical leaves using the nondestructive Minolta chlorophyll meter model SPAD 502 (SPAD is an acronym for soil plant analysis development) [21].

c- Total carbohydratescontent of cane:During the dormancy period (the last week of December), samples were taken from the basal part of shoots ( 2 buds) and cut into small pieces, oven-dried at $70^{\circ} \mathrm{C}$ for 72 hours and ground for the determination of total carbohydrates. In samples of 0.1 g.dried material, total carbohydrates were determined colorimetrically at 490-mu wavelength, using the phenol sulfuric acid method as described by DuBois et al. [22]. Total carbohydrates content were calculated as g. glucose / $100 \mathrm{~g}$ dry weight using glucose standard curve.

Representative samples of 18 clusters /treatment (6 cluster from each replicate) were collected randomly when clusters reached to $15 \%$ T.S.S for cluster and berry analysis.

\section{Yield}

a- Average 25 berries weight (g).

b- Average 25 berries size $\left(\mathrm{cm}^{3}\right)$. c- Average cluster weight (g).

d- Total yield/vine: It was carried out at the normal commercial harvesting time in the last week of May. The number of clusters per vine was recorded, the average weight of each cluster was estimated (in grams) and the total yield per vine was expressed in kilograms.

\section{Chemical characteristics of berries}

a- Total Soluble Solids (T.S.S. \%) was determined in the juice by hand refractometer [17].

b- Titratable Acidity (as gram tartaric acid/100 ml juice) was determined by titration against $\mathrm{NaOH}$ using phenolphthalein as an indicator.[17]

c- Total Soluble Solids /acid ratio were calculated.

d- Total Indole content (mg/100g. D.W.) was determined according to P-dimethyl aminobenzaldhyde test [23] to obtain a stable pink color to be colorimetrically estimated then the concentration was calculated from a standard curve of indole acetic acid.

e- Total phenolic content: was determined using the Folin-Ciocalteu assay according to Singleton and Rossi [24].

\section{Statistical analysis}

The statistical analysis of the present data was carried out according to Snedecor and Cochran [25]. Significance differences among the means of various treatments using Duncan's multiple range test as 5\% level according to Waller and Duncan [26].

\section{Results and Discussion}

Morphological measurements of leaves and shoots Average leaf area and pruning weight/vine:

Leaf area development is an important characteristic affecting yield and fruit quality of grapevines. Table (3) shows the effect of different treatments on the average leaf area of superior seedless. It is obvious from the recorded data that there are significant differences among treatments. The highest values were obtained from vines treated with $100 \%$ IC + Bio followed by $50 \% \mathrm{M}$ $+50 \%$ IC + Bio, $100 \%$ IC alone, $50 \% \mathrm{M}+50 \%$ IC then $100 \% \mathrm{M}+$ Bio. There were significant differences between different treatments except for 
$100 \%$ IC and $50 \% \mathrm{M}+50 \%$ IC + Bio in the $1 \mathrm{st}$ season and $100 \% \mathrm{IC}+\mathrm{Bio}$ and $50 \% \mathrm{M}+50 \% \mathrm{IC}$ + Bio in the 2nd season. It is evident from the obtained data in Table (3) that there is a significant stimulation on shoot length with increasing irradiated compost application. This stimulation was augmented by the addition of microbein biofertilizer. The vines of $100 \%$ IC + Bio gave the highest value for pruning weight while, the lowest value was given by $100 \% \mathrm{M}$ treated vines.

These results are in harmony with those of Akparobi [27] who found that increasing manure application for Amaranthus cruentus plants up to $35 \mathrm{t} / \mathrm{ha}$ were associated with increased leaf area per plant. Similarly, Ayeni and Oye [28] found that application of organic fertilizers increased leaf area of Corchorus olitorius L. Application of manure together with Azotobacter biofertilizer with a reduced dose of inorganic fertilizers significantly increased the leaf area of mulberry as compared to manure and organic fertilizers application [29]. It was found that combined use of mineral and biofertilization significantly increased leaf area of flame seedless grapevines [30]. Moreover, using suitable N (100g/vine) as 50\% inorganic plus 50\% organic and biofertilizers resulted in enhancing the growth characters of Banaty grapevines rather than application of mineral $\mathrm{N}$ alone [31]. The beneficial effect of organic fertilizers on leaf area of plants could be related to the improvement of physical conditions of the soil, providing energy from microorganism activity, increasing nutrient supply and improving the efficiency of macro elements as well as its ability to meet some micronutrient requirements [32]. In addition, the beneficial effect of the biofertilizer may be

Table (1): Soil physical and chemical properties

\begin{tabular}{|c|c|c|}
\hline Soil properties & Season2015 & Season2016 \\
\hline Soil texture & Loamy sand & Loamy sand \\
\hline Sand (\%) & 84.5 & 84.0 \\
\hline Clay (\%) & 4.0 & 3.0 \\
\hline Silt (\%) & 11.5 & 13.0 \\
\hline $\mathbf{p H}$ & 8.01 & 8.0 \\
\hline $\mathbf{C l}^{-}$ & 92.4 & 71.6 \\
\hline $\mathbf{S O}_{\mathbf{4}}$ & 11.9 & 12.9 \\
\hline $\mathbf{C a}$ & 27.00 & 23.5 \\
\hline $\mathbf{M g}$ & 20.3 & 15.9 \\
\hline $\mathbf{N a}$ & 57.2 & 44.3 \\
\hline $\mathbf{K}$ & 1.5 & 1.3 \\
\hline $\mathbf{H C O} \mathbf{3}(\%)$ & 1.7 & 1.5 \\
\hline $\mathbf{E C}$ & 10.99 & 8.81 \\
\hline
\end{tabular}

attributed to its effect on increasing nitrogen fixation, production of growth promoting substances or organic acids and enhancing nutrient uptake [33].

\section{Yield}

Average berry weight and average berry size:

Berry weight is an important quality parameter for table grapes and affects yield. The mean values of berry weight of treated grapevines are displayed in Table (3). The results of statistical analysis indicate that there were significant differences in berry weights between treatments, with a superior effect attributed to using irradiated $100 \%$ IC + Bio, followed by $50 \% \mathrm{M}+50 \% \mathrm{IC}+\mathrm{Bio}, 100 \% \mathrm{IC}$ alone. The effect of $100 \%$ IC + Bio on berry weight was significantly superior or similar to $50 \%$ $\mathrm{M}+50 \%$ IC. The least berry weight was obtained in vines treated with $100 \%$ M. Data in Table (3) revealed that application of irradiated compost alone or in combination with the biofertilizer enhanced the berry size. The berry size of superior grapefollowed the same trend previously mentioned for berry weight. These results were similar to those obtained by Sánchez et al. [34] and Ferrara and Brunetti [35] who reported that application of humic acid, the most active components of compost organic matter, caused a significant increase in berry size. Similarly, the application of mineral and biofertilizer significantly increased berry size as compared to mineral fertilizer alone [30]. The application of mineral $\mathrm{N}$ fertilizer and composted municipal solid waste with biofertilizers on thomson seedless grapevine resulted in a positive significant effect on berry weight [36].

Table (2): Compost physical and chemical properties

\begin{tabular}{|c|c|c|}
\hline Compost properties & Season 2015 & Season2016 \\
\hline Organic matter (\%) & 45 & 46 \\
\hline Organic carbon (\%) & 23.6 & 24.2 \\
\hline Moisture content (\%) & 33 & 32 \\
\hline Total nitrogen (\%) & 1.83 & 1.71 \\
\hline Soluble ammonium (ppm) & 689 & 675 \\
\hline Soluble nitrate (ppm) & 232 & 219 \\
\hline P(\%) & 0.89 & 0.86 \\
\hline K (\%) & 0.85 & 0.79 \\
\hline C/N ratio & $14.5: 1$ & $14.2: 1$ \\
\hline pH value (1:10) & 6.8 & 7.1 \\
\hline EC value (1:10) (dS/m) & 5.5 & 5.2 \\
\hline
\end{tabular}


Table (3): The effect of NPK, irradiated compost and biofertilizers on morphological measurements of leaves, pruning/vin and yield components of superior seedless grapevine during the two successive seasons 2015 and 2016

\begin{tabular}{|c|c|c|c|c|c|c|c|c|c|c|c|c|}
\hline \multirow{2}{*}{ Treatments } & \multicolumn{2}{|c|}{$\begin{array}{c}\text { Leaf area }\left(\mathrm{Cm}^{2} \text { /leaf }\right. \\
\text { (1) }\end{array}$} & \multicolumn{2}{|c|}{ Pruning/vine (Kg) } & \multicolumn{2}{|c|}{$\begin{array}{l}25 \text { berries weight } \\
\text { (g.) }\end{array}$} & \multicolumn{2}{|c|}{$\begin{array}{c}25 \text { berries size } \\
\left(\mathrm{Cm}^{3}\right)\end{array}$} & \multicolumn{2}{|c|}{$\begin{array}{c}\text { Cluster weight } \\
\text { (g.) }\end{array}$} & \multicolumn{2}{|c|}{ Yield/vine (Kg) } \\
\hline & 2015 & 2016 & 2015 & 2016 & 2015 & 2016 & 2015 & 2016 & 2015 & 2016 & 2015 & 2016 \\
\hline $100 \% \mathrm{M}$ & $94.9 \mathrm{~d}$ & $98.8 \mathrm{~d}$ & $2.50 \mathrm{e}$ & $3.00 \mathrm{e}$ & $105.3 \mathrm{c}$ & $111.1 \mathrm{~d}$ & $102.7 \mathrm{~d}$ & $105.7 \mathrm{c}$ & $313.3 \mathrm{e}$ & $352.5 \mathrm{e}$ & $12.5 \mathrm{e}$ & $14.1 \mathrm{e}$ \\
\hline $100 \% \mathrm{M}+\mathrm{Bio}$ & $107.2 \mathrm{c}$ & $107.5 \mathrm{~cd}$ & $4.17 \mathrm{~d}$ & $4.50 \mathrm{~d}$ & $108.8 \mathrm{bc}$ & $127.9 \mathrm{~b}$ & $107.7 \mathrm{c}$ & $117.0 \mathrm{~b}$ & $350.0 \mathrm{~d}$ & $446.7 \mathrm{c}$ & $14.0 \mathrm{~d}$ & $17.9 \mathrm{c}$ \\
\hline $50 \% \mathrm{M}+50 \%$ IC & $116.7 \mathrm{~b}$ & $111.5 \mathrm{bc}$ & $7.17 \mathrm{c}$ & $7.33 \mathrm{c}$ & $112.7 \mathrm{bc}$ & $119.1 \mathrm{c}$ & $109.3 \mathrm{c}$ & $110.0 \mathrm{c}$ & $428.3 \mathrm{c}$ & $420.8 \mathrm{~d}$ & $17.1 \mathrm{c}$ & $16.8 \mathrm{~d}$ \\
\hline $50 \% \mathrm{M}+50 \% \mathrm{IC}+\mathrm{Bio}$ & $120.8 \mathrm{ab}$ & $121.8 \mathrm{a}$ & $9.83 \mathrm{~b}$ & $10.17 \mathrm{~b}$ & $125.1 \mathrm{a}$ & $130.6 \mathrm{~b}$ & $115.2 \mathrm{ab}$ & $126.0 \mathrm{a}$ & $458.3 \mathrm{~b}$ & $490.8 \mathrm{~b}$ & $18.3 \mathrm{~b}$ & $19.6 \mathrm{~b}$ \\
\hline $100 \%$ IC & $122.8 \mathrm{ab}$ & $117.8 \mathrm{ab}$ & $10.17 \mathrm{~b}$ & $10.83 \mathrm{ab}$ & $116.1 \mathrm{ab}$ & $128.8 \mathrm{~b}$ & $111.0 \mathrm{bc}$ & $120.7 \mathrm{~b}$ & $465.0 \mathrm{~b}$ & $483.3 \mathrm{~b}$ & $18.6 \mathrm{~b}$ & $19.3 \mathrm{~b}$ \\
\hline $100 \%$ IC+ Bio & $128.6 \mathrm{a}$ & $124.0 \mathrm{a}$ & $11.83 \mathrm{a}$ & $12.00 \mathrm{a}$ & $125.5 \mathrm{a}$ & $137.8 \mathrm{a}$ & $117.7 \mathrm{a}$ & $127.7 \mathrm{a}$ & $545.0 \mathrm{a}$ & $519.8 \mathrm{a}$ & $21.8 \mathrm{a}$ & $20.8 \mathrm{a}$ \\
\hline
\end{tabular}

Average cluster weight and total yield per vine: Generally, it could be noticed from Table (3) that average cluster weight and total yield significantly increased by soil application of irradiated compost and or biofertilizer. The average cluster weight and total yield of vines treated with $100 \%$ IC + Bio was significantly higher than all other treatments. The application of $100 \%$ IC or $50 \%$ M+ $50 \%$ IC + Bio has a similar effect on average cluster weight and total yield. Application of 50\% M $+50 \%$ IC was superior to $100 \% \mathrm{M}+\mathrm{Bio}$ as it significantly increased both the average cluster weight and the total yield. The highest rate of increasing was obtained by $100 \%$ IC + Bio treated vines $(74 \%$ \& $72.4 \%$ for cluster weight and $74.4 \%$ \& $73.1 \%$ for total yield, of both seasons respectively). As for the total vine yield, soil application of $50 \%$ IC to $50 \%$ mineral fertilization was associated with increasing the rate of $35.2 \%$ \& $28.4 \%$ for both seasons, respectively as compared to $100 \%$ mineral fertilization. While, application of $100 \%$ IC alone increased the total yield by $10.7 \% \& 13.4 \%$ as compared to $50 \% \mathrm{IC}+50 \% \mathrm{M}$. The rate of increment in total yield due to addition of microbein to $100 \%$ mineral fertilization was $16 \%$ and $12.7 \%$ for both seasons, respectively. Moreover, its addition to $100 \%$ IC resulted in increment rate of $17.8 \%$ and $21.5 \%$ for both seasons, respectively.

Similar results were obtained by Akparobi [27] who found that fresh weight and dry weight per plant Amaranthus cruentus increased with the increase in quantity of manure applied and Liu et al. [37] who reported that sludge compost treatment resulted in significant improvement in reproductive development of wine grape. Tomato yields increased with rate of application of irradiated and non-irradiated sewage sludge [38]. Similarly, gamma irradiated compost produced higher maize yield as compared to mineral fertilization [13]. Compost is very beneficial in increasing the productivity of fruit crops due to the conversion of unavailable minerals into soluble forms that plants can use, reducing their leaching and enhancing the uptake of nitrogen by plants [39]. Also, biofertilizers significantly increased total yield and clusters weight of flame seedless grapevines as compared with mineral fertilization [30]. Microbein is found to be favorable in improving nutritional status, yield, physical and chemical properties of grapevines.[40] The combined use of organic and biofertilization in addition to mineral fertilizer significantly increased the total yield of mango [41]. The effect of biofertilization might be related to the improvement of the physical conditions of soil providing energy for micro-organisms, activity and increasing the availability and uptake of $\mathrm{N}, \mathrm{P}$ and $\mathrm{K}$, which was reflected on growth [42].

\section{Chemical characteristics of leaves and shoots Petiole mineral content of NPK\%:}

The concerned results in Table, (4) indicate that, petiole $\mathrm{N} \%$ was significantly increased by increasing rate of irradiated compost and or microbein addition. The highest value obtained in vines received $100 \%$ IC + Bio $(5.00 \%$ and $4.83 \%$ for both seasons, respectively), followed by $100 \%$ IC alone, $50 \% \mathrm{M}+50 \% \mathrm{IC}+\mathrm{Bio}, 50 \% \mathrm{M}+50 \%$ IC, then $100 \% \mathrm{M}+$ Bio and finally, $100 \% \mathrm{M}(3.10$ and $3.03 \%$ for both seasons, respectively). The P\% followed the same trend exhibited by $\mathrm{N} \%$ as the highest value was obtained by vines treated with $100 \%$ IC + Bio $(1.24 \%$ and $1.26 \%$ for both seasons, respectively). However, there was no significant difference between petiole $\mathrm{P} \%$ of vines treated with $100 \%$ IC and 50\% M + 50\% IC + Bio. The addition of irradiated compost and or 
microbein significantly affects petiole $\mathrm{K} \%$ (Table, 4). Increasing the rates of irradiated compost application did not significantly increase $\mathrm{K} \%$ in the $1^{\text {st }}$ season however the reverse was seen in the $2^{\text {nd }}$ season. It is worth noting that, the addition of biofertilizer did not significantly affect $\mathrm{K} \%$ in both season except when added to $100 \% \mathrm{M}$. The percentage of increase due to application of $50 \%$ IC $+50 \% \mathrm{M}$ was $22.58 \% \& 18.81 \%$ for $\mathrm{N} \%, 13.4 \%$ \& $7 \%$ for $\mathrm{P} \%$ and $15 \%$ \& $14.29 \%$ for $\mathrm{K} \%$. Application of $100 \%$ IC showed percentage of increase $50.65 \%$ \& $46.20 \%$ for $\mathrm{N} \%, 19.57 \%$ \& $11 \%$ for $\mathrm{P} \%$ and $16 \%$ \& $19.39 \%$ for $\mathrm{K} \%$. Data revealed that the addition of microbein to previous treatment enhanced the percentage of increase. The highest percentage of increase obtained by $100 \% \mathrm{IC}+$ Bio $(61.29 \%$ \& $59.41 \%$ for $\mathrm{N} \%$, $34.78 \% \& 26 \%$ for $\mathrm{P} \%$ and $21 \%$ \& $21.43 \%$ for $\mathrm{K}$ $\%)$.

These results are in agreement with those obtained by Popovic et al. [43] who reported that organic fertilization of grape vine significantly increased nitrogen and phosphorus contents in the leaves compared to mineral fertilizers, however, it did not express considerable influence over the content of potassium in the leaves. Grapevine treated with 40 t/ha farmyard manure resulted in statistically significant highest potassium leaf content as compared to control treatment [44]. Additionally, organic fertilization of cordons increased NPK content that was correlated with the dose of fertilizer [9]. In the same manner, mineral fertilizers combined with biofertilization resulted in higher NP\%, but had no effect on K\% in flame seedless grapevines as compared to mineral fertilization only [30]. The positive effect of organic fertilizers could be attributed to the marked increase of $\mathrm{NO}$ and enhanced soil available $\mathrm{P}$, and increased $\mathrm{NO}_{3}{ }^{-}$in the soil due to nitrification in comparison with similar rates of non-irradiated sludge. However, extra application of irradiated sludge did not further increase the $\mathrm{NO}_{3}{ }^{-}$level [45]. In addition, irradiation of sludge causes releases of $\mathrm{NH}_{4}{ }^{+}$and increased the bioavailability of $\mathrm{N}$ [46]. Moreover, biofertilizers help in availability of mineral and their forms in the composted material and increase levels of extractable NPK [47].

Leaf total chlorophyll content and total carbohydrates content of cane:

It is clear from the data in Table (4) that total chlorophyll content in the leaves was positively affected by the application of the irradiated compost and or microbein. A significant enhancement of total leaf chlorophyll content was recorded as a result of either increased rate of irradiated compost or microbein application. The maximum value of total chlorophyll content was recorded by vines that received $100 \%$ IC + Bio at both seasons. There was nosignificant difference between values obtained by $50 \% \mathrm{M}+50 \% \mathrm{IC}+$ Bio and that of $100 \%$ IC alone in the $1^{\text {st }}$ season. However, at the $2^{\text {nd }}$ season, $50 \% \mathrm{M}+50 \% \mathrm{IC}+$ Bio was significantly superior where its value was not significantly different from those of $100 \%$ IC + Bio. The total chlorophyll content of vines treated with $50 \% \mathrm{M}+50 \%$ IC was superior to those of $100 \% \mathrm{M}+$ Bio only in the $2^{\text {nd }}$ season. In general, the carbohydrate content of grapevines canes was significantly enhanced by increasing the rate of irradiated compost and or addition of microbein. The results showed that combined use of $100 \%$ IC + Bio gave the highest cane carbohydrate content for both seasons. Moreover, vines that received $100 \%$ IC alone or $50 \% \mathrm{M}+50 \%$ IC + Bio gave almost similar results for both seasons (Table, 4). The application of 50\% M +50\% IC increased the total chlorophyll by rate of $(7.96 \% \& 11.07 \%$ for both seasons, respectively) and total carbohydrates at rate of $(9.03 \% \& 11.51 \%$ for both seasons, respectively) as compared to control (100\% M).The addition of microbein to $50 \% \mathrm{M}+50 \%$ IC increased total chlorophyll and carbohydrates by $11.22 \% \& 16.06 \%$ and $16.73 \%$ \& $19.17 \%$ for both seasons, respectively as compared to those without microbein. These parameters were increased by $14.59 \% \& 16.70 \%$ and $24 \% \& 27.70 \%$ when microbein was added to $100 \%$ IC.

The present results are in harmony with Abd-ElWahab [48] who found that application of 50\% mixed manure (compost and chicken manure) combined with application of 50\% mineral nitrogen fertilizer significantly increased leaf chlorophyll. Gamma-irradiated sludge significantly increased the total protein and starch content of methi (Trigonella foenum-graecum L.) [49] and total leaf chlorophyll content [50]. Chlorophyll a, b and carotenoids were also increased in Salix viminals $L$. plants treated with biostimulator application ${ }^{[51]}$. The beneficial effect of irradiated compost in increasing the total chlorophyll may be due to the positive influence upon the biosynthesis of the primary metabolites (soluble carbohydrates, chlorophyll and carotenoid pigments) and 
secondary metabolites (proteins, polyphenols, auxins) in the leaf, during the vegetation season [11].

\section{Chemical characteristics of berries}

Total soluble solids (TSS \%), Titratable acidity (TA \%) and TSS / TA ratio:

Data in Table, (5) show that the application of 50\% irradiated compost had a little effect on TSS\% as compared to $100 \% \mathrm{M}$ compost, while, $100 \%$ irradiated compost significantly increased TSS\% as compared to the case of adding $100 \% \mathrm{M}$ or $50 \%$ irradiated compost. The addition of biofertilizer significantly enhanced the TSS\% as compared to those without biofertilizers. Regarding TA\%, both irradiated compost at different rates and biofertilizer significantly decreased TA\% with the lowest value recorded by $100 \%$ IC + Bio $(0.715$ and $0.699 \%$ for both seasons, respectively). TSS/TA\% was significantly increased in response to increased irradiated compost application and or biofertilization. There were significant differences between different treatments except for $100 \% \mathrm{M}$ and $100 \% \mathrm{M}+\mathrm{Bio}$ in both seasons.

The present results are in accordance with those of Liu et al. [37] who found that sludge treatment significantly increased soluble solids content and decreased acidity of wine grape.Compost tea was an effective treatment in enhancing the TSS \% and TSS/acidity ratio whereas; acidity was decreased in berry juice [52]. Similarly, biofertilizer significantly increased T.S.S and decreased juice acidity of flame seedless grapevines [30]. Treatment combinations of organic and biofertilizer showed the highest total soluble solids and total sugar content of fruit [53]. This result may be due to the fact that organic fertilizers are rich in their content of macro and micro elements which led to enhance photosynthesis; this means that more sugar (glucose) is available for growth and fruit ripening [54]. In addition, increased total sugars were mainly due to growth enhancement and increases in chlorophyll content, which increased photosynthesis [38].

Total indoles content and total phenolic content: Data in Table (5) ensure that increased rate of irradiated compost application is associated with significant increase of total indole content. Additional use of biofertilizer (microbein) did not affect the total iodole content in the $1^{\text {st }}$ season. However, in the $2^{\text {nd }}$ season its addition to $100 \% \mathrm{M}$ or $100 \%$ IC significantly increased total indole content. For total phenolic content, $100 \%$ IC + Bio was better than the other treatments in increasing the phenolic content. Irradiated compost or biofertilizer induced a significant increase in the total phenolic content. Liu et al. [37] found that sludge treatment resulted in a significant increase in the total phenol content when compared to the control. The promoting effect of organic and biofertilization on the fruit quality was mainly attributed to their essential role in enhancing organic foods especially total carbohydrates and plant pigments which is reflected on advancing fruit maturity [55]. Moreover, microorganisms have an important role in nitrogen fixation, ability to synthesize indole, acetic acid and gibberellins like substances, which gave additional advantages in the field bio- production [56].

Table (4): The effect of NPK, irradiated compost and biofertilizers on some chemical characteristics of superior seedless grapevine leaves during the two successive seasons 2015 and 2016

\begin{tabular}{|c|c|c|c|c|c|c|c|c|c|c|}
\hline \multirow{3}{*}{ Treatments } & \multicolumn{6}{|c|}{ Petiole mineral content } & \multirow{2}{*}{\multicolumn{2}{|c|}{$\begin{array}{c}\text { Total } \\
\text { chlorophyll } \\
\text { mg/100 g. F.W. }\end{array}$}} & \multirow{2}{*}{\multicolumn{2}{|c|}{$\begin{array}{c}\text { Total } \\
\text { carbohydrates } \\
\text { g./100 g. D.W. }\end{array}$}} \\
\hline & \multicolumn{2}{|c|}{$\mathrm{N} \%$} & \multicolumn{2}{|c|}{$\mathbf{P} \%$} & \multicolumn{2}{|r|}{$\mathbf{K} \%$} & & & & \\
\hline & $015^{2}$ & $016^{2}$ & $5^{201}$ & $16^{20}$ & $015^{2}$ & $6^{201}$ & $5^{201}$ & $6^{201}$ & $5^{201}$ & $6^{201}$ \\
\hline $100 \% \mathrm{M}$ & $10 \mathrm{~d}^{3 .}$ & $03 \mathrm{~d}^{3 .}$ & $2 \mathrm{~d}^{0.9}$ & $0 \mathrm{c}^{1.0}$ & $00 \mathrm{~b}^{1 .}$ & $8 \mathrm{c}^{0.9}$ & $80 \mathrm{c}^{36 .}$ & $50 \mathrm{~d}^{35 .}$ & $79 \mathrm{c}^{27 .}$ & $89 \mathrm{~d}^{29 .}$ \\
\hline $100 \% \mathrm{M}+\mathrm{Bio}$ & $33 \mathrm{~cd}$ & $43 \mathrm{c}^{3 .}$ & $6 \mathrm{~cd}^{0.9}$ & $2 \mathrm{c}^{1.0}$ & $06 \mathrm{ab}$ & $5 \mathrm{bc}{ }^{1.0}$ & $30 \mathrm{c}^{37 .}$ & $40 \mathrm{c}^{37 .}$ & $37 \mathrm{bc} 29$. & $25 \mathrm{~cd}^{31 .}$ \\
\hline $50 \% \mathrm{M}+50 \% \mathrm{IC}$ & $80 \mathrm{c}^{3 .}$ & $60 \mathrm{c}^{3 .}$ & $4 \mathrm{bc}{ }^{1.0}$ & $7 \mathrm{bc}$ & $15 \mathrm{a}^{1 .}$ & $2 \mathrm{ab}{ }^{1.1}$ & $70 \mathrm{~b}^{39 .}$ & $43 \mathrm{~b}^{39 .}$ & $30 \mathrm{bc}$ & $33 \mathrm{bc}$ \\
\hline $\begin{array}{l}50 \% \mathrm{M}+50 \% \mathrm{IC} \\
+\mathrm{Bio}\end{array}$ & $33 \mathrm{~b}^{4 .}$ & $07 \mathrm{~b}^{4}$ & $1 \mathrm{~b}^{1.1}$ & $2 \mathrm{~b}^{1.1}$ & $15 \mathrm{a}^{1 .}$ & $4 \mathrm{ab}$ & $\begin{array}{r}40 . \\
90 \mathrm{ab} \\
\end{array}$ & $20 \mathrm{a}^{41 .}$ & $\begin{array}{l}32 . \\
44 \mathrm{ab} \\
\end{array}$ & $\begin{array}{l}35 . \\
62 \mathrm{ab} \\
\end{array}$ \\
\hline $100 \% \mathrm{IC}$ & $67 \mathrm{ab}^{4 .}$ & $43 \mathrm{~b}^{4}$ & $0 \mathrm{~b}$ & $1 \mathrm{~b}^{1.1}$ & $16 \mathrm{a}^{1 .}$ & $7 \mathrm{a}^{1.1}$ & $90 \mathrm{a}^{41 .}$ & $\begin{array}{l}40 . \\
77 \mathrm{ab}\end{array}$ & $28 \mathrm{ab}^{32 .}$ & $24 \mathrm{ab}$ \\
\hline $100 \% \mathrm{IC}+\mathrm{Bio}$ & $00 \mathrm{a}^{5 .}$ & $83 \mathrm{a}^{4 .}$ & $4 \mathrm{a}{ }^{1.2}$ & $6 \mathrm{a}^{1.2}$ & $21 \mathrm{a}^{1 .}$ & $9 \mathrm{a}{ }^{1.1}$ & $17 \mathrm{a}^{42 .}$ & $43 \mathrm{a}^{41 .}$ & $46 \mathrm{a}^{34 .}$ & $17 \mathrm{a}^{38 .}$ \\
\hline
\end{tabular}

$\mathrm{M}=\mathrm{NPK}$ fertilizers, $\mathrm{IC}=$ irradiated compost and $\mathrm{Bio}=$ microbeen

* Means with different letters are significantly different at $\mathrm{p}<0.05$. 
Table (5): The effect of NPK, irradiated compost and biofertilizers on some chemical characteristics of berries of superior seedless grapevine during the two successive seasons 2015 and 2016

\begin{tabular}{|c|c|c|c|c|c|c|c|c|c|c|}
\hline \multirow[b]{2}{*}{ Treatments } & \multicolumn{2}{|c|}{ T.S.S \% } & \multicolumn{2}{|c|}{ Acidity \% } & \multicolumn{2}{|c|}{ T.S.S/ acid ratio } & \multicolumn{2}{|c|}{$\begin{array}{l}\text { Total indoles } \\
\text { (mg./100g. D.W.) }\end{array}$} & \multicolumn{2}{|c|}{$\begin{array}{l}\text { Total phenols } \\
\text { (mg./100g. D.W.) }\end{array}$} \\
\hline & $15^{20}$ & 2016 & $5^{201}$ & $6^{201}$ & 2015 & $6^{201}$ & $5^{201}$ & $6^{201}$ & $5^{201}$ & $6^{201}$ \\
\hline $100 \% \mathrm{M}$ & $50 \mathrm{~b}^{15 .}$ & $7 \mathrm{c}^{15.1}$ & $41 \mathrm{a}^{0.8}$ & $23 \mathrm{a}^{0.8}$ & 18.4 & $43 \mathrm{~d}^{18 .}$ & $41 \mathrm{~b}^{0.0}$ & $45 \mathrm{~b}^{0.0}$ & $12 \mathrm{~d}^{0.1}$ & $19 \mathrm{~d}^{0.1}$ \\
\hline $100 \% \mathrm{M}+\mathrm{Bio}$ & $83 \mathrm{~b}^{15 .}$ & $0 \mathrm{bc}$ & $23 \mathrm{~b}^{0.8}$ & $06 \mathrm{~b}^{0.8}$ & 19.2 & $23 \mathrm{~d}^{19 .}$ & $43 \mathrm{~b}^{0.0}$ & $48 \mathrm{ab}^{0.0}$ & $26 \mathrm{~d}^{0.1}$ & $28 \mathrm{~cd}^{0.1}$ \\
\hline $50 \% \mathrm{M}+50 \% \mathrm{IC}$ & $67 \mathrm{~b}^{15 .}$ & $7 \mathrm{abc}^{16.1}$ & $93 \mathrm{c}^{0.7}$ & $64 \mathrm{c}^{0.7}$ & $6 \mathrm{~cd}^{19.7}$ & $16 \mathrm{c}^{21 .}$ & $52 \mathrm{ab}^{0.0}$ & $53 \mathrm{ab}^{0.0}$ & $45 \mathrm{c}^{0.1}$ & $37 \mathrm{bc}$ \\
\hline $\begin{array}{l}50 \% \mathrm{M}+50 \% \mathrm{IC} \\
+ \text { Bio } \\
\end{array}$ & $\begin{array}{l}16 . \\
33 \mathrm{ab}\end{array}$ & $0 \mathrm{ab}^{16.5}$ & $64 \mathrm{~d}^{0.7}$ & $46 \mathrm{~d}^{0.7}$ & $8 \mathrm{bc}{ }^{21.3}$ & $12 \mathrm{bc}$. & $\begin{array}{l}0.0 \\
54 \mathrm{ab}\end{array}$ & $\begin{array}{l}0.0 \\
56 \mathrm{ab}\end{array}$ & $\begin{array}{r}0.1 \\
58 \mathrm{bc} \\
\end{array}$ & $46 \mathrm{~b}^{0.1}$ \\
\hline $100 \% \mathrm{IC}$ & $\begin{array}{l}16 . \\
67 \mathrm{ab} \\
\end{array}$ & $\begin{array}{ll} & 16.8 \\
3 \mathrm{a} & \\
\end{array}$ & $43 \mathrm{e}^{0.7}$ & $19 \mathrm{e}^{0.7}$ & $3 \mathrm{ab}^{22.4}$ & $\begin{array}{r}23 . \\
42 \mathrm{ab} \\
\end{array}$ & $62 \mathrm{a}^{0.0}$ & $\begin{array}{r}0.0 \\
61 \mathrm{ab} \\
\end{array}$ & $\begin{array}{r}0.1 \\
74 \mathrm{ab} \\
\end{array}$ & $67 \mathrm{a}^{0.1}$ \\
\hline 100\% IC+ Bio & $17 \mathrm{a}^{17 .}$ & $\begin{array}{ll} & 17.0 \\
0 \mathrm{a} & \end{array}$ & $15 \mathrm{f}^{0.7}$ & $99 \mathrm{f}^{0.6}$ & 24.0 & $33 \mathrm{a}^{24 .}$ & $64 \mathrm{a}^{0.0}$ & $65 \mathrm{a}^{0.0}$ & $77 \mathrm{a}^{0.1}$ & $76 \mathrm{a}^{0.1}$ \\
\hline
\end{tabular}

* Means with different letters are significantly different at $\mathrm{p}<0.05$.

\section{Conclusion}

$100 \%$ Irradiated compost with microbein was an effective treatment in increasing the yield and enhancing the physical and chemical characteristics of berriesas. The berry size, weight, TSS $\%$ and TSS/acidity ratio were increased whereas, the acidity\% was decreased. Also, they improved vegetative growth parameters and increased the petiole NPK \%, leaf chlorophyll content and cane carbohydrate content more than the other treatments and the control. The cluster weight was significantly increased as a result of increasing the yield per vine in both seasons. This provided an increment of $74.4 \%$ \& $73.1 \%$ for both seasons compared to the control, which can be a valid alternative to the expensive hazardous mineral fertilizers.

\section{References}

1- Bedrech, S.A. Efficacy of Adding Some Organic Nutrition on Reducing the Rates of Mineral Fertilizers in Flame Seedless Grapevine, J. Biol. Chem. Environ. Sci., 11 (4), 741-483(2016).

2- Chude, V.O., Malgwi, W.B., Amapu, I.V. and Ano, O.A. Manual on Soil Fertilit Assessment, Federal Fertilizer Department (FFD) Incollaboration with FAO/National Special Programme for Food Security, Abuja, Nigeria, (2004).

3- Yagodin, B.A. Agricultural Chemistry. Mir Publishers Moscow, pp: 278-281(1990).

4- Remison, S.U. (2005) Basic Principles of Crop Physiology, Sadoh Press Nig, Benin City.

5- Hilbert, G., Soyer, J.P., Molot, C., Giraudon, J., Milin, S. and Gaudillere, J.P. Effects of Nitrogen Supply on Must Quality and Anthocyanin Accumulation in Berries of cv. Merlot, Vitis, 42, 69-76(2003).
6- Smil, V. Enriching the earth: Fritz Haber, Carl Bosch, and the transformation of world food production. MIT press (2004) .

7- Peyvast, G., Kharazi, P. R., Tahernia, S., Nosratierad, Z., \& Olfati, J. A. Municipal Solid Waste Compost Increased Yield and Decreased Nitrate Amount of Broccoli, J. Appl. Hort., 10 (2), 129-131(2008).

8- Greene, C. US Organic Agriculture Gaining Ground, Agricultural Outlook, (270), 9-14(2000).

9- Sala, F., and Blidariu, C. Macro-and Micronutrient Content in Grapevine Cordons under the Influence of Organic and Mineral Fertilization, Bulletin UASVM Horticulture, 69 (1), 317-324(2012).

10- Rasmussen, P.E., and Parton, W.J. Long-Term Effects of Residue Management in Wheat-Fallow: I. Inputs, Yield, and Soil Organic Matter, Soil Science Society of America Journal, 58 (2), 523530(1994).

11- Bejan, C., and Vişoiu, E. The Accumulation of Biochemical Compounds in the Grapevine Leaves as an Effect of the Organic Fertilization of the Viticultural Soil, Annals of the University of Craiova-Agriculture, Montanology, Cadastre Series, 40 (1), 15-20(2010).

12- Wen, G., Bates, T.E., Voroney, R.P., Yamamoto, T., Chikushi, J., and Curtin, D. A Yield Control Approach to Assess Phytoavailability of $\mathrm{Zn}$ and $\mathrm{Cu}$ in Irradiated, Composted Sewage Sludge and Composted Manure in Field Experiments: I. Zinc, Plant and soil, 246 (2), 231-240(2002).

13- Pradhan, S.K., Nikiema, J., Cofie, O.O., HeinonenTanski, H., and Drechsel, P. Fecal Sludge-Derived Pellet Fertilizer in Maize Cultivation, Journal of Water Sanitation and Hygiene for Development, 6 (3), 474-481(2016).

14- Chirinos, J., Leal, A., and Montilla, J. Use Alternative Biological Inputs for Sustainable Agriculture in the South of Anzoategui State, Applied and Interdisciplinary Sciences, 
Biotechnology. Digital Magazine Ceniap Today, 11, 1-7(2006).

15- Marangoni, B., Toselli, M., Venturi, A., Fontana, M., and Scudellari, D. Effects of Vineyard Soil Management and Fertilization on Grape Diseases and Wine Quality, IOBC WPRS BULLETIN, 24 (5), 353-358(2001).

16- Richards, L.A. Diagnosis and Improvement of Saline and Alkali Soils. United States Department of Agriculture, Washington, D.C .USA(1969).

17- A.O.A.C. Official Methods of Analysis of the Association of Official Analytical Chemists, 15th Ed. Washington D.C., U.S.A(1990).

18- Selim, H.H., Fayek, M.A. and Sweidan, A.M. Reproduction of Bircher Apple Cultivar by Layering, Annals of Agri. Sci. Moshtohor, 9, 156166(1978).

19- Wild, S.A., Corey, R.B., Iyer, J.G., and Voigt, G.K. Soil and Plant Analysis for Tree Culture, Oxford and IPH publishing Co., New Delhi, India, pp: 529 546(1985).

20- Chapman, H.D., and Pratt, P.F. Methods of Analysis for Soils, Plants and Waters, Soil Science, 93 (1), 68(1962).

21- Wood, C.W. Relationships between Chlorophyll Meter Readings and Leaf Chlorophyll Concentration, N Status, and Crop Yield: A Review, In Proc Agron Soc NZ, 23, 1-9(1993).

22- DuBois, M., Gilles, K.A., Hamilton, J.K., Rebers, P.T., and Smith, F. Colorimetric Method for Determination of Sugars and Related Substances, Analytical chemistry, 28 (3), 350356(1956).

23- Larsen, P., Harbo, A., Klungsöyr, S., and Aasheim, T. On the Biogenesis of Some Indole Compounds in Acetobacter Xylinum, Physiol. Plant., 15 (3), 552-565(1962).

24- Singleton, V.L., and Rossi, J.A. Colorimetry of Total Phenolics with PhosphomolybdicPhosphotungstic Acid Reagents, American journal of Enology and Viticulture, 16 (3), 144-158(1965).

25- Snedecor, G.W.W and Cochran, W.G. Statistical Methods, Iowa State University Press/Ames, 177195(1980).

26- Waller, R.A., and Duncan, D.B. A Bayes Rule for the Symmetric Multiple Comparisons Problem. Journal of the American Statistical Association, 64 (328), 1484-1503(1969).

27- Akparobi, S.O. Effect of Farmyard Manures on the Growth and Yield of Amaranthus Cruentus, Agric. Trop. Et Subtrop, 42, 1-4(2009).

28- Ayeni, M.J and Oye, O.V. Effect of Different Organic Fertilizers on the Growth Performance of Corchorus Olitorius L, IOSR Journal of Agriculture and Veterinary Science (IOSR-JAVS), 10 (4): 3844(2017).

29- Chakraborty, B. and kundu, M. Effect of Biofertilizer in Combination with Organic Manures on Growth and Foliar Constituents of Mulberry under Rainfed Lateritic Soil Condition, The International Journal of Engineering and Science (IJES), 4 (3), 16-20(2015).

30- Khalil, H.A. The Potential of Biofertilizers to Improve Vegetative Growth, Nutritional Status, Yield and Fruit Quality of Flame Seedless Grapevines, American-Eurasian J. Agric. \& Environ. Sci, 12 (9), 1122-1127(2012).

31- Dakhly, O.F., Ahmed, F.F., Rizk, I.A., and Uwakiem, M.K.H. Response of Young Banaty Grapevines to Biofertilization with some Mutants Produced from Azotobacter Vinelandii, In 8th African Crop Science Society Conference, ElMinia, Egypt, 27-31 October 2007 (pp. 395-406). African Crop Science Society(2007).

32- El-Nagar, E.M. Effect of Applying some Organic Residues to Sandy and Calcareous Soils on Growth and Composition of Some Plants, (Doctoral dissertation, MSc thesis, Faculty of Agriculture, Mansoura University, Mansoura, Egypt) (1996) .

33- Samah, Y.A.E. Effect of Biofertilizer on Yield and Berry Qualities of Grapevines, (Doctoral dissertation, M. Sc. Thesis. Fac. Agric., Mansoura Univ., Egypt(2002) .

34- Sánchez-Sánchez, A., Sánchez-Andreu, J., Juárez, M., Jordá, J., and Bermúdez, D. Improvement of Iron Uptake in Table Grape by Addition of Humic Substances, J. plant Nutr., 29 (2), 259-272(2006).

35- Ferrara, G., and Brunetti, G. Effects of the Times of Application of a Soil Humic Acid on Berry Quality of Table Grape (Vitis vinifera L.) cv Italia. Spanish Journal of Agricultural Research, 8 (3), 817822(2010).

36- Eman, A.A., El-Monem, A., Saleh, M.M.S., and Mostafa, E.A.M. Minimizing the Quantity of Mineral Nitrogen Fertilizers on Grapevine by Using Humic Acid, Organic and Biofertilizers, Res. J. Agric. Biol. Sci, 4, 46-50(2008).

37- Liu, H.T., Wang, Y.W., Huang, W.D., and Lei, M. Response of Wine Grape Growth, Development and the Transfer of Copper, Lead, and Cadmium in Soil-Fruit System to Sludge Compost Amendment, Environ. Sci. Pollut. Res., 23 (23), 24230-24236(2016).

38- El-Motaium, R., and Badawy, S. H. Irradiated Sewage Sludge for Increased Crop Production-ii. Effects on Soil Properties and Tomato Yields. Irradiated sewage sludge for application to cropland, 75(2002).

39- Omar, A.H. Fertilization of Thompson Seedless Vines with Mineral and Organic Sources of Nitrogen, J. Agric. Sci. Mansoura Univ., 30 (12), 7855-7862(2005).

40- El-Naggar, A.M.A. Effect of Organic Farming on Drip Irrigation Grapevine and Soil Chemical Properties, In Proceeding of the 2nd International Conference of Agriculture, 117-128(2004). 
41- Kundu, S., Datta, P., Mishra, J., Rashmi, K., and Ghosh, B. Influence of Biofertilizer and Inorganic Fertilizer in Pruned Mango Orchard cv. Amrapali, Journal of crop and weed, 7 (2), 100103(2011).

42- Romero-Lima, M.D.R., Trinidad-Santos, A., García-Espinosa, R., and Ferrera-Cerrato, R. Yield of Potato and Soil Microbial Biomass with Organic and Mineral Fertilizers, Agrociencia, 34 (3), 261269(2000).

43- Popović, T., Mijović, S., and Pajović, R. The Substance of Nitrogen, Phosphorus and Potassium in Leaves of the Vine" Vranac", Depending of the Sort of Fertilizer, in the Comparative Conditions of Irrigation or Non-Irrigation, Agroznanje-Agroknowledge Journal, 10 (4), 59-65(2009).

44- Karažija, T., Ćosić, T., Horvat, T., Poljak, M., and Lazarević, B. Effects of Organic Fertilization on Potassium Content and Dynamics in Grapevine Leaf (Vitis Vinifera L.) on Calcareous Soil, In 46th Croatian and 6th International Symposium on Agriculture, Opatija, Croatia, 14-18 February 2011. Proceedings (pp. 112-115). University of Zagreb Faculty of Agriculture(2011).

45- Magnavacca, C., and Graino, J. G. Additional Advantages of Irradiation Treatment of Sewage SludgefFor Agriculture Re-Use, Proc. Int. Symp. on Nuclear Techniques in Integrated Plant Nutrient, Water and Soil Management, 16-20 October, IAEA, Vienna (No. IAEA-SM--363) (2000) .

46- Magnavacca, C. Evaluation of Irradiated Sewage Sludge as an Industrial Crop Fertilizer Using Nuclear Techniques. Irradiated sewage sludge for application to cropland, 5-12(2002).

47- El-Kramany, M.F., Ahmed, M.K.A., Bahr, A.A., and Kabesh, M.O. Utilization of Biofertilizers in Field Crop Production. 13-Effect of Organic Manuring, Chemical and Biofertilizers on Yield and Nutrient Content of Sesame Grown In Newly Reclaimed Soil, Egypt. J. Appl. Sci., 15 (11), 137 155(2000).
48- El-Wahab, M.A. Reducing the Amount of Mineral Nitrogen Fertilizers for Red Globe Grapevines by Using Different Sources of Organic Fertilizers, J. Amer. Scie., 7 (8):810-819(2011).

49- Pandya, G.A., Banerjee, S., and Modi, V.V. Perspectives of Recycling Gamma Irradiated Sewage-Sludge in Agricultural Applications: a study on methi (Trigonella foenum-graecum L.: leguminosae), Environ. Pollut., $72 \quad$ (3), 225237(1991)

50- Awad, S.M. Effect of Irradiated Poultry Manure on Growth and Leaf Nutrients Content of Grape Transplants, Annals Agric. Sci. (Cairo), 45 (1), 315-325(2000).

51- Wróbel, J., and Woźniak, A. The Effect of Atonik Plant Growth Stimulator on Chemical Composition of Common Osier Salix Viminalis L., Grown in Different Substrates, In Proc. Conf. Biostimulators in modern agriculture, 7-8(2008).

52- Omar, A.S.M. Using Different Sources of Compost Tea on Grapes, M. Sc. Thesis, Fac. Agric., Mansoura Univ(2013).

53- Devi, H.L., Mitra, S.K., and Poi, S.C. Effect of Different Organic and Biofertilizer Sources on Guava (Psidium Guajava L.)'Sardar', In III International Symposium on Guava and other Myrtaceae 959, 201-208(2012).

54- Keller, M., Arnink, K.J., and Hrazdina, G. Interaction of Nitrogen Availability during Bloom and Light Intensity During Veraison. I. Effects on Grapevine Growth, Fruit Development, and Ripening, Amer. J. Enol. \& Vit., 49 (3), 333340(1998).

55- Nijjar, G.S. Nutrition of Fruit Trees, Published by Mrs Usha Raj umar for Kalyani, India, New Delhi, 10-52(1985).

56- Subba, R.N.S. Biofertilizers in Agriculture, Oxford and IBH Publishing Co., New Delhi, Bombay Calcutta, 342(1993). 